\title{
Dissolution of Dense Lime in Molten Slags under Static Conditions
}

\author{
Shahriar AMINI, ${ }^{1)}$ Michael BRUNGS ${ }^{2)}$ and Oleg OSTROVSKI ${ }^{3)}$ \\ 1) Formerly, School of Chemical Sciences and Engineering, The University of New South Wales and CSIRO Minerals. Now at \\ School of Chemical Engineering and Analytical Science, The University of Manchester, UK., PO Box 88, Sackville St., \\ Manchester, M60 1 QD, UK. E-mail: shahriar.amini@manchester.ac.uk \\ The University of New South Wales, NSW, 2052, Australia. \\ 2) School of Chemical Sciences and Engineering, \\ 3) School of Material Sciences and Engineering, The
} University of New South Wales, NSW, 2052, Australia.

(Received on July 3, 2006; accepted on September 20, 2006)

\begin{abstract}
Static dissolution of $\mathrm{CaO}$ into a $\mathrm{CaO}-\mathrm{SiO}_{2}-\mathrm{Al}_{2} \mathrm{O}_{3}$ slag with fluxing agents (fluorspar, ilmenite and nepheline syenite) was studied using two experimental techniques. In one method, the slag was packed into dense $\mathrm{CaO}$ crucibles, and heated to $1500^{\circ} \mathrm{C} / 1600^{\circ} \mathrm{C}$. After reaction, the crucible was air cooled and cross-sectioned. In the second technique, slag with a piece of lime was heated in a platinum capsule. The development of the $\mathrm{Ca}_{2} \mathrm{SiO}_{4}$ phase at the lime/slag interface and the $\mathrm{CaO}$ dissolved in the slag from the lime specimen were examined by Electron Probe Micro Analysis and Scanning Electron Microscopy. IImenite and nepheline syenite were found to be effective substitutes for fluorspar, increasing the $\mathrm{CaO}$ dissolution rate in the slag.
\end{abstract}

KEY WORDS: lime; dissolution; slag; fluorspar; nepheline syenite; ilmenite.

\section{Introduction}

Product quality and efficiency in the steelmaking industry are influenced by the chemical and rheological properties of the slag produced as an integral part of the operation. The chemistry of the slag is controlled by the addition of lime and other fluxes. Fluxes are required in steelmaking basically for two purposes. Firstly, to lower the melting point of slags so that slags of higher basicity can be used to reduce the level of residuals in steel. Secondly, to decrease the viscosity of slags and thus speed up refining reactions. BOF steelmaking and ladle refining operations are normally run with slag of high basicity, which is achieved by introduction of high volumes of lime. Efficient steelmaking practice requires rapid assimilation of lime by slag, which is influenced strongly by temperature and slag composition. Mechanisms of lime dissolution into slag under different conditions have been studied previously. ${ }^{1-9)}$

Umakoshi et al., ${ }^{2)}$ studied the dissolution of a rotating burnt dolomite cylinder in $\mathrm{Fe}_{t} \mathrm{O}-\mathrm{CaO}-\mathrm{SiO}_{2}$ slag as a function of temperature $\left(1350-1400^{\circ} \mathrm{C}\right)$ and rotational speed. They found a film of $\mathrm{Ca}_{2} \mathrm{SiO}_{4}$ at a short distance from the $\mathrm{CaO}$ interface which hindered the dissolution of $\mathrm{CaO}$. They also concluded that the dissolution rate was affected by the (Fe, $\mathrm{Mg}$ )O solid solution, which was formed on the surface of the burnt lime. Matsushima et al. ${ }^{6}$ investigated the dissolution of solid lime by dipping a crystalline lime cylinder into the static $\mathrm{CaO}-\mathrm{SiO}_{2}-\mathrm{Al}_{2} \mathrm{O}_{3}$ and $\mathrm{FeO}-\mathrm{CaO}-\mathrm{SiO}_{2}$ slag bath at $1400^{\circ} \mathrm{C}$ and $1500^{\circ} \mathrm{C}$ and measured the concentration profile in the vicinity of interface. It was shown that
$\mathrm{Ca}_{2} \mathrm{SiO}_{4}$ precipitated slightly apart from the interface and the slag near the interface was enriched in $\mathrm{Al}_{2} \mathrm{O}_{3}$ or $\mathrm{FeO}$, which indicated silica depletion due to the formation of the $\mathrm{Ca}_{2} \mathrm{SiO}_{4}$ film. These results seemed to confirm the long held belief that when lime is immersed in slag; a layer of di-calcium silicate is formed that slows down the dissolution process.

Fluxes such as fluorspar are usually added to increase the rate of lime dissolution. However, fluorspar causes emission of hazardous fluoride species, leaching of fluoride from generated slag, and refractory wear. These factors and dwindling accessible supplies of fluorspar have stimulated a search for alternative fluxes. The possibility of fluorspar substitution has been previously examined by a number of researchers. ${ }^{10-17)}$ Tribe et al. ${ }^{13)}$ presented a series of laboratory and industrial tests in which fluorspar in steelmaking slag was partially or fully replaced with feldspathoid mineral (a group of sodium and potassium aluminosilicate). They found that nepheline syenite tailing (NST) can be a suitable substitute for the fluorspar. NST slag exhibited a similar rheological behaviour to the $\mathrm{CaF}_{2}$ slag. Also, when using NST, the steel chemistry was not affected and adequate desulphurisation was achieved. Singh et al. ${ }^{16)}$ conducted extensive industrial trials to show that the fluidity of slag with ilmenite $\left(\mathrm{FeTiO}_{3}\right)$ is very close to the fluidity of the fluorspar-containing slag, and concluded that ilmenite can be used as a fluorspar replacement in open hearth steelmaking. Poggi et al. ${ }^{17)}$ also found that the fluorspar and ilmenite have close melting points and both are very fluid when molten. 
The current study examines the dissolution of lime at steelmaking temperatures in calcium alumino-silicate slags with basicity of 1 . The aim of this study is to examine the effect of addition of $10 \mathrm{wt} \%$ fluxing agents: fluorspar, nepheline syenite and ilmenite on the rate of lime dissolution in the slag. While acknowledging that in industry, the burnt lime is porous (more than $50 \%$ porosity for softburnt lime and about $25 \%$ porosity for hard-burnt), it was decided to use a low porosity lime $(8.4 \%)$. This was to ensure a sharp lime/slag boundary and consequently better control of experimental conditions.

\section{Experimental}

Static dissolution of $\mathrm{CaO}$ into slag was studied by two experimental techniques. Firstly, holding slag in a dense lime crucible, varying reaction time, temperature and slag chemistry. Secondly, by reacting a piece of lime with slag in a small platinum crucible, varying temperature.

\subsection{Materials}

Manufacture of the lime crucibles included the following operations. The limestone powder with $50-70 \mu \mathrm{m}$ particle size was milled with alumina balls producing $0.8-1 \mu \mathrm{m}$ particles that were then calcined to $\mathrm{CaO}$ and pressed in a mould and subsequently fired to provide the necessary density and strength. This technique allowed a close control of bulk density and apparent porosity by precisely varying compacting pressure, sintering temperature, rate of heating and cooling and sintering time.

The experimental slags were prepared in a platinum crucible by melting a mixture of slag components, quenching the melt and then re-melting to ensure slags' homogeneity. The master slag was a three component $\mathrm{CaO}-\mathrm{SiO}_{2}-\mathrm{Al}_{2} \mathrm{O}_{3}$ system with $45 \mathrm{wt} \% \mathrm{CaO}, 45 \mathrm{wt} \% \mathrm{SiO}_{2}$, and $10 \mathrm{wt} \% \mathrm{Al}_{2} \mathrm{O}_{3}$. Flux additions were made by adding $10 \mathrm{wt} \%$ of fluorspar and fluorspar replacement candidates to the master slag. The flux compositions used in the present work are presented in Table 1 and the chemical composition of slags studied in the present work are tabulated in Table 2. In the case of the $\mathrm{CaF}_{2}$ addition, subsequent analysis revealed that

Table 1. Chemical compositions of fluxes.

\begin{tabular}{|c|c|c|c|}
\hline \multicolumn{2}{|c|}{ (a) nepheline syenite } & \multicolumn{2}{|c|}{ (b) ilmenite } \\
\hline Oxides & $\mathrm{Wt} \%$ & Oxides & $\mathrm{Wt} \%$ \\
\hline $\mathrm{SiO}_{2}$ & 59.30 & $\mathrm{TiO}_{2}$ & 55.3 \\
\hline $\mathrm{Al}_{2} \mathrm{O}_{3}$ & 19.28 & $\mathrm{Fe}_{2} \mathrm{O}_{3}$ & 24.1 \\
\hline $\mathrm{Fe}_{2} \mathrm{O}_{3}$ & 2.25 & $\mathrm{FeO}$ & 16 \\
\hline $\mathrm{CaO}$ & 0.91 & $\mathrm{Al}_{2} \mathrm{O}_{3}$ & 0.58 \\
\hline $\mathrm{MgO}$ & 0.09 & $\mathrm{SiO}_{2}$ & 0.93 \\
\hline $\mathrm{Na}_{2} \mathrm{O}$ & 8.33 & $\mathrm{MnO}$ & 1.48 \\
\hline $\mathrm{K}_{2} \mathrm{O}$ & 5.32 & $\mathrm{P}_{2} \mathrm{O}_{5}$ & 0.03 \\
\hline $\mathrm{FeO}$ & 2.27 & $\mathrm{Cr}_{2} \mathrm{O}_{3}$ & 0.045 \\
\hline
\end{tabular}

the $\mathrm{CaF}_{2}$ content of the resultant slag was only $5.7 \mathrm{wt} \%$ indicating a loss of fluorine. The fluorine loss and oxidation of calcium of fluorspar was previously reported by Shimizu et al. ${ }^{18)}$

\subsection{Experimental Procedure}

The dissolution of dense lime in molten slag was studied at 1500 and $1600^{\circ} \mathrm{C}$ as a function of time and slag composition. After cooling the samples the chemical composition of various elements in the liquid slag and also phase identification were quantitatively performed by EPMA mapping and SEM analysis.

In the first experimental technique performed at The University of New South Wales, the $\mathrm{CaO}$ crucible was filled with slag and charged to the muffle furnace. A sample was heated slowly at $100^{\circ} \mathrm{C} / \mathrm{h}$ up to $1250^{\circ} \mathrm{C}$ which is below the melting point of slag studied in this work, in order to minimize the risk of thermal shock in the crucible and then heated quickly at $600^{\circ} \mathrm{C} / \mathrm{h}$ up to $1500^{\circ} \mathrm{C} / 1600^{\circ} \mathrm{C}$. Zero reaction time was defined as the time when the furnace first reached the desired temperature. After the required reaction times of 30 and $60 \mathrm{~min}$, the crucible and slag were taken out of the furnace and quickly quenched in air. Due to the severe thermal shock, in most cases and especially experiments at $1600^{\circ} \mathrm{C}$, the lime crucible was shattered into pieces after air quenching, making it difficult to prepare a sample of lime with attached slag for further analysis. The recovered crucible with its slag content was cross-sectioned and mounted in resin.

Samples were prepared with a flat and well-polished surface, finished to $(0-1) \mu \mathrm{m}$ and then coated with a carbon layer (thickness $\sim 200 \AA$ ) for electron probe microanalysis (EPMA). A CAMECA SX50 EPMA at The University of New South Wales was used in quantitative analysis of samples. All samples were examined using an accelerating voltage of $15 \mathrm{kV}$, a beam current of $20 \mathrm{nA}$ and a beam size of $1 \mu \mathrm{m}$. Point analysis was performed for each distinct phase identified using back-scattered electron mode. A MATLAB $^{19)}$ program was developed to convert the concentration profile of each element in the matrix to the mole percentage of various oxides and determined the phase locations in the ternary phase diagram. The phase diagrams at different temperatures were obtained from FactSage. ${ }^{20)}$ The elemental distribution in the slag adjacent to the lime/slag interface was mapped by $2 \mu \mathrm{m}$ step size stage movement in an area of 512 by $512 \mu \mathrm{m}$ size and at a 256 by 256 image resolution. A MATLAB program was also developed to analyze the results from mapping. The program enabled recognition of $\mathrm{Ca}_{2} \mathrm{SiO}_{4}$ and $\mathrm{Ca}_{3} \mathrm{SiO}_{5}$ phases in the mapped area.

The formation of solid phases formed at the $\mathrm{CaO}$ crucible/slag interface was further investigated by carrying out another series of static experiments at Commonwealth Sci-

Table 2. Chemical compositions of slags.

\begin{tabular}{|c|c|c|c|c|c|c|c|c|}
\hline Slag & $\mathrm{CaO}$ & $\mathrm{SiO}_{2}$ & $\mathrm{Al}_{2} \mathrm{O}_{3}$ & $\mathrm{CaF}_{2}$ & $\mathrm{Na}_{2} \mathrm{O}$ & $\mathrm{K}_{2} \mathrm{O}$ & $\mathrm{Fe}_{2} \mathrm{O}_{3}$ & $\mathrm{TiO}_{2}$ \\
\hline master slag & 45.3 & 45 & 9.7 & - & - & - & - & - \\
\hline slag + $\mathrm{CaF}_{2}$ & 44.4 & 40.7 & 9.1 & 5.7 & - & - & - & - \\
\hline slag + nepheline syenite & 41 & 46.2 & 10.5 & - & 0.9 & 0.6 & 0.9 & - \\
\hline slag + ilmenite & 40.5 & 41.1 & 8.7 & - & - & - & 3.9 & 5.9 \\
\hline
\end{tabular}


entific and Industrial Research Organization (CSIRO) division of Minerals, in which a platinum capsule was used to contain the slag and a piece of lime. The small platinum capsules ( $15 \mathrm{~mm}$ ID by $32 \mathrm{~mm}$ height) were made by welding two sides of a thin platinum foil. About $0.5 \mathrm{~g}$ of slag and $0.6-0.7 \mathrm{~g}$ of dense chipped $\mathrm{CaO}$ from crucible pieces were contained in the platinum capsule and were held vertically by shallow holes drilled in a refractory brick. The muffle furnace was ramped up to $1000^{\circ} \mathrm{C}$ at the rate of $100^{\circ} \mathrm{C} / \mathrm{h}$ and then to the target temperature at the rate of $800^{\circ} \mathrm{C} / \mathrm{h}$. After reaching the temperatures of 1500 and $1600^{\circ} \mathrm{C}$ and exposure at temperature for the required reaction time, the platinum capsules were taken out of the muffle furnace and rapidly quenched on a brass plate, which was also cooled by an air flow on its back surface. The use of thin and small platinum foil in this technique provided a very fast cooling rate compared to the previous technique. The samples from the reaction experiments were cut, mounted in resin and coated with a carbon layer. These samples were analyzed using a Philips XL30 Scanning Electron Microscope at University of Melbourne. The electron optical system accelerating voltage was $20 \mathrm{kV}$.

\section{Experimental Results and Discussion}

Electron Micrographs of the sample at $1500^{\circ} \mathrm{C}$ from the lime crucible experiment (Fig. 1(a)) show formation of a $\mathrm{Ca}_{2} \mathrm{SiO}_{4}$ layer, which was also observed by Matsushima et $a l .{ }^{6)}$ However at $1600^{\circ} \mathrm{C}$, no discrete layer of $\mathrm{Ca}_{2} \mathrm{SiO}_{4}$ was detected (Fig. 1(b)). The dendritic appearance of the crys-

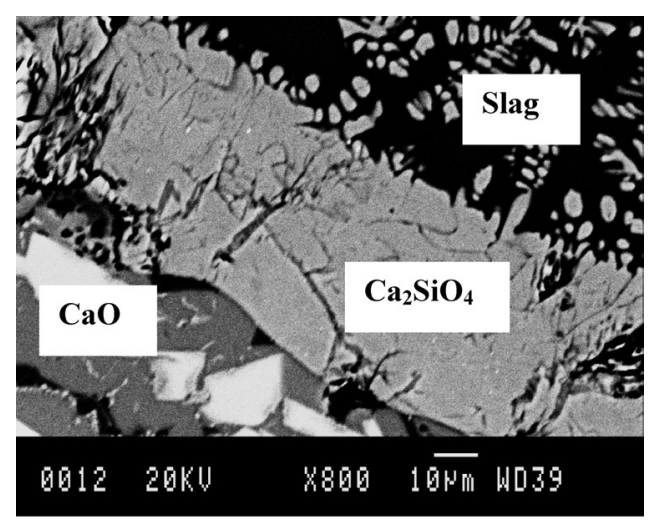

(a)

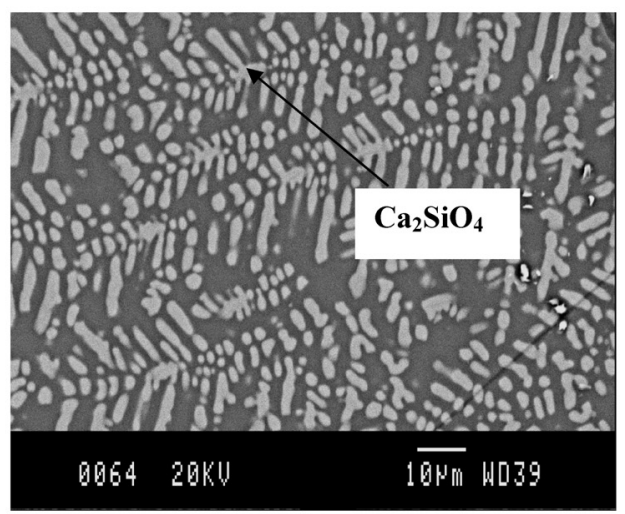

(b)

Fig. 1. SEM of base slag in the lime crucible experiments for time $=0$ with 1000 magnification at (a) $1500^{\circ} \mathrm{C}$, (b) $1600^{\circ} \mathrm{C}$. tallites indicates that they were not present in the liquid phase but crystallised out during cooling. Although a layer of $\mathrm{Ca}_{2} \mathrm{SiO}_{4}$ was not observed at $1600^{\circ} \mathrm{C}$, it does not mean that it was not formed at this temperature. The loss of materials at the lime/slag interface because of the lime crucible shattering on air quenching or the loss of the layer in sample preparation cannot be excluded. "Slag composition" is the composition of the slag at experimental temperatures determined by analysis of quenched samples that consisted of both crystalline and glassy phases. Where the composition of these phases has been determined, it will be referred to as the crystalline or glassy phase composition.

Change in the slag chemical and phase composition in the process of lime dissolution measured by EPMA at $1500^{\circ} \mathrm{C}$ is shown in the $\mathrm{CaO}-\mathrm{SiO}_{2}-\mathrm{Al}_{2} \mathrm{O}_{3}$ phase diagram in Fig. 2. After achieving $1500^{\circ} \mathrm{C}$ (zero time), $\mathrm{CaO}$ concentration in the slag increased from the initial 45 to $48 \mathrm{wt} \%$. After $30 \mathrm{~min}$ reaction, it reached $52 \mathrm{wt} \%$ and increased further to $54 \mathrm{wt} \%$ after $60 \mathrm{~min}$. In the $\mathrm{CaO}-\mathrm{SiO}_{2}-\mathrm{Al}_{2} \mathrm{O}_{3}$ phase diagram, these compositions are within the liquid area (Fig. $2)$. At zero reaction time, the observed presence of the $\mathrm{Ca}_{2} \mathrm{SiO}_{4}$ phase at the slag crucible boundary (Fig. 1(a)) is the result of local non equilibrium conditions. The growth rate of di-calcium layer at $1500^{\circ} \mathrm{C}$ was measured by line scan with EPMA. The thickness of the layer is shown in Table 3. The measurement shows that at zero reaction time, the $\mathrm{Ca}_{2} \mathrm{SiO}_{4}$ layer has already been formed with a thickness of $164 \mu \mathrm{m}$, although the $\mathrm{CaO}$ content in the liquid slag was outside the $\mathrm{Ca}_{2} \mathrm{SiO}_{4}$-liquid equilibrium curve. This means

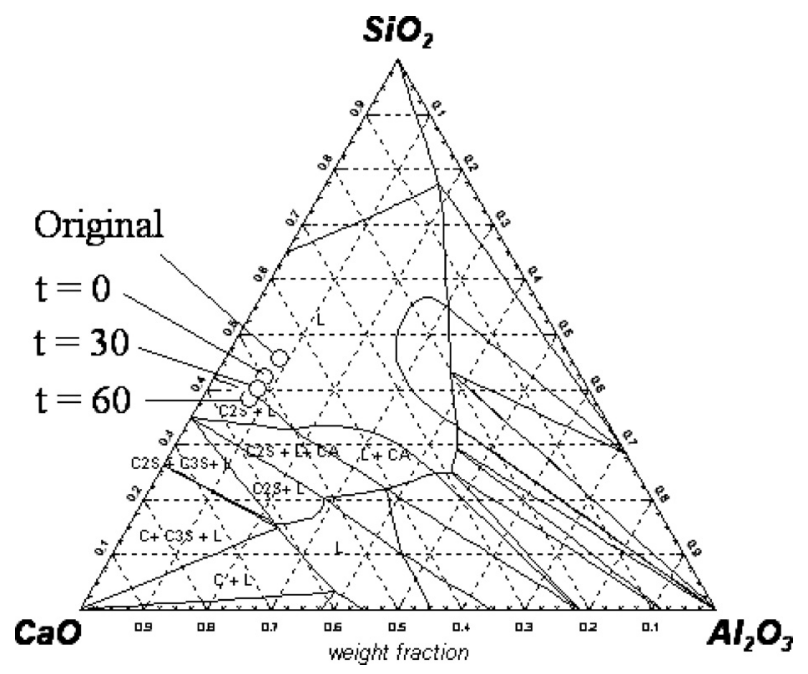

Fig. 2. The composition of bulk slag at various reaction times (min) in phase diagram for basic slag at $1500^{\circ} \mathrm{C}$.

Table 3. Growth of $\mathrm{Ca}_{2} \mathrm{SiO}_{4}$ layer at $1500^{\circ} \mathrm{C}$ when the slag is reacted with $\mathrm{CaO}$ in the lime crucible and platinum capsule.

\begin{tabular}{|c|c|c|}
\hline \multirow{2}{*}{$\begin{array}{c}\text { Reaction time } \\
\text { (minutes) }\end{array}$} & \multicolumn{2}{|c|}{ Thickness of $\mathrm{Ca}_{2} \mathrm{SiO}_{4}$ layer $(\mu \mathrm{m})$ at $1500{ }^{\circ} \mathrm{C}$} \\
\cline { 2 - 3 } & $\mathrm{CaO}$ Crucible & Platinum Crucible \\
\hline 0 & 164 & 94 \\
\hline 30 & 192 & 191 \\
\hline 60 & 321 & 199 \\
\hline
\end{tabular}




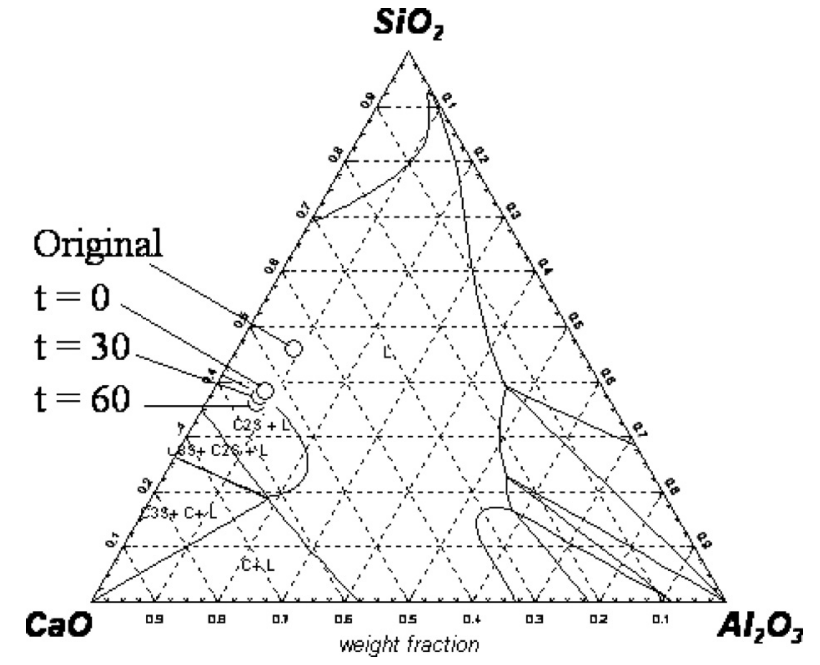

Fig. 3. The composition of bulk slag at various reaction times (min) in phase diagram for basic slag at $1600^{\circ} \mathrm{C}$.

that dissolution of lime into the slag occurred through the di-calcium silicate layer. The liquid phase composition achieved the equilibrium with $\mathrm{Ca}_{2} \mathrm{SiO}_{4}\left(\mathrm{Ca}_{2} \mathrm{SiO}_{4}\right.$-liquid curve on the phase diagram) in $30 \mathrm{~min}$. Slag $\mathrm{CaO}$ concentration increased slightly further with $1 \mathrm{~h}$ exposure. Obviously the dissolution of lime has been hindered by the formation of the $\mathrm{Ca}_{2} \mathrm{SiO}_{4}$ layer, and the rate of the $\mathrm{Ca}_{2} \mathrm{SiO}_{4}$ layer growth was greater than the its dissolution rate. The growth of the $\mathrm{Ca}_{2} \mathrm{SiO}_{4}$ layer was accompanied by a change in the chemistry of the liquid slag along the $\mathrm{Ca}_{2} \mathrm{SiO}_{4}$-liquid curve in accordance with the phase diagram in Fig. 2; the liquid slag was depleted of $\mathrm{SiO}_{2}$ and enriched with $\mathrm{Al}_{2} \mathrm{O}_{3}$, while the $\mathrm{CaO}$ concentration in liquid phase changed slightly, although its total concentration increased as a result of increasing thickness of the $\mathrm{Ca}_{2} \mathrm{SiO}_{4}$ layer.

At $1600^{\circ} \mathrm{C}$ the change in slag chemical and phase composition in process of lime dissolution measured by EPMA is shown in the $\mathrm{CaO}-\mathrm{SiO}_{2}-\mathrm{Al}_{2} \mathrm{O}_{3}$ phase diagram in Fig. 3. The initial dissolution rate of $\mathrm{CaO}$ into the slag was much faster than at $1500^{\circ} \mathrm{C}$. By "zero" reaction time, $\mathrm{CaO}$ concentration in the slag increased from 45 to $53 \mathrm{wt} \%$, which is very close to the $\mathrm{Ca}_{2} \mathrm{SiO}_{4}$-liquid equilibrium curve. Change in the slag's $\mathrm{CaO}$ content with increasing reaction time was small (to 54-55 wt\%) indicating that dissolution of lime had slowed dramatically and at this $\mathrm{CaO}$ content, the slag is saturated with di-calcium silicate. The composition of liquid slag analyzed by EPMA revealed an increase in alumina and a decrease in silica in the slag which indicates formation of the di-calcium silicate phase. Total content of $\mathrm{CaO}$ in the slag was about the same at $1500^{\circ} \mathrm{C}$ and $1600^{\circ} \mathrm{C}$ after dissolution for $30 \mathrm{~min}(52-54 \mathrm{wt} \%)$ and $60 \mathrm{~min}(53-$ $55 \mathrm{wt} \%$ ). The fact that the $\mathrm{CaO}$ content of slag has not been increased at $1600^{\circ} \mathrm{C}$ and after $1 \mathrm{~h}$ of reaction shows that a layer of di-calcium was formed on the lime and slag interface.

In experiments, conducted in platinum capsule, a solid phase product layer was formed between the lime particles and the slag at both temperatures, which was identified by EDS analysis as $\mathrm{Ca}_{2} \mathrm{SiO}_{4}$. At $1500^{\circ} \mathrm{C}$, the formation of reaction layer at the lime/slag interface at $1500^{\circ} \mathrm{C}$ for the reaction times of 0,30 and $60 \mathrm{~min}$ was in agreement with the

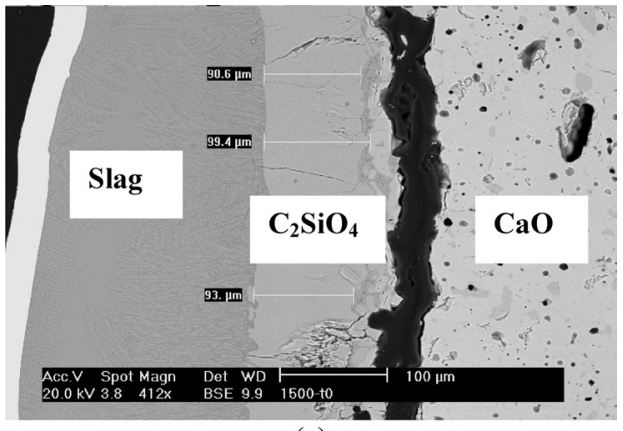

(a)

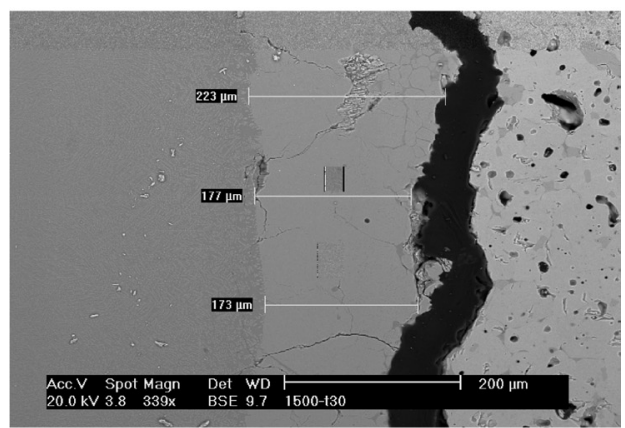

(b)

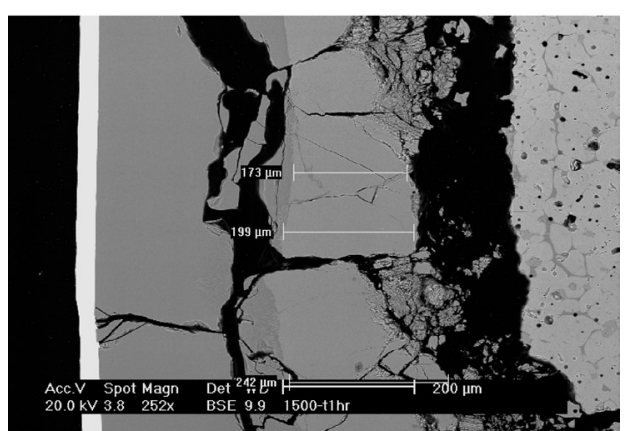

(c)

Fig. 4. Identified layer of $\mathrm{Ca}_{2} \mathrm{SiO}_{4}$ on the lime/slag interface by $\mathrm{SEM}$ when lime was reacted with slag in a platinum capsule at $1500^{\circ} \mathrm{C}$ for reaction times of (a) 0 , (b) $30 \mathrm{~min}$ and (c) $60 \mathrm{~min}$.

observation from the previous experimental series. The micrographs of the reaction layer at $1500^{\circ} \mathrm{C}$ and its growth is illustrated in Fig. 4. The average growth rate of the di-calcium layer as shown in Table 3 differs from the result of the experiments conducted in lime crucible. This could be due to the different slag to lime specimen ratio and also different cooling rate in both experimental techniques.

At $1600^{\circ} \mathrm{C}$, the experiments with platinum capsule were performed at the reaction times of 15,30 and $60 \mathrm{~min}$. The sample recovery during these experiments was more difficult than the experiments done at $1500^{\circ} \mathrm{C}$. The results for experiments at 15 and $60 \mathrm{~min}$ of reaction time shown in Fig. 5 clearly indicate the formation of $\mathrm{Ca}_{2} \mathrm{SiO}_{4}$, which grows with time. For the experiment at reaction time of $30 \mathrm{~min}$, the $\mathrm{Ca}_{2} \mathrm{SiO}_{4}$ was not recovered; it was presumably lost during quenching.

Mass balance calculations, based on the EPMA analysis of a glassy phase, were used to estimate the quantity of calcium oxide transferred to the slag at $1600^{\circ} \mathrm{C}$ with addition of various fluxes in the lime crucible experiments (Table 4). The underlying assumption was that the increased alumina 


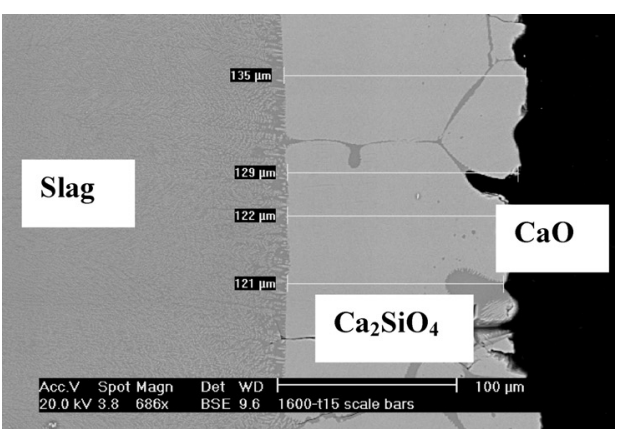

(a)

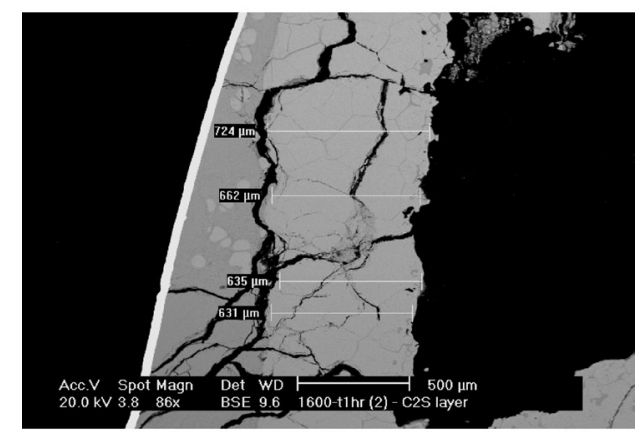

(b)

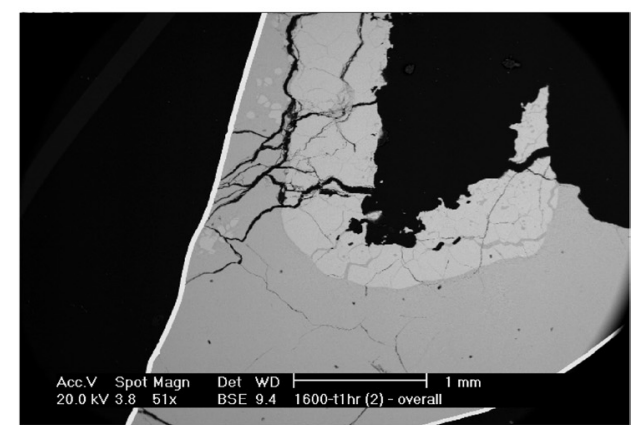

(C)

Fig. 5. Identified layer of $\mathrm{Ca}_{2} \mathrm{SiO}_{4}$ on the lime/slag interface by SEM when lime was reacted with slag in a platinum capsule at $1600^{\circ} \mathrm{C}$ for reaction times of (a) $15 \mathrm{~min}$, (b) $60 \mathrm{~min}$, (c) overview of platinum capsule with slag and reaction layer after $60 \mathrm{~min}$ of reaction.

Table 4. Mass (g) of $\mathrm{CaO}$ dissolved in the slags (per $100 \mathrm{~g}$ of slag) at $1600^{\circ} \mathrm{C}$.

\begin{tabular}{|c|c|c|c|}
\hline $\begin{array}{l}\text { Reaction time } \\
\text { (minutes) }\end{array}$ & 0 & 30 & 60 \\
\hline Master slag & 17 & 19.5 & 19.9 \\
\hline Slag + $\mathrm{CaF}_{2}$ & 15 & 16 & 20 \\
\hline Slag + N.S & 18.7 & 23.3 & 26.3 \\
\hline Slag + ilmenite & 29.4 & 30.8 & 30 \\
\hline
\end{tabular}

content of the glassy phase had to be the result of precipitation of $\mathrm{Ca}_{2} \mathrm{SiO}_{4}$. The mass of the glassy phase was calculated from the $\mathrm{Al}_{2} \mathrm{O}_{3}$ mass balance and the mass of di-calcium silicate from the $\mathrm{SiO}_{2}$ mass balance, and finally the $\mathrm{CaO}$ transferred to the slag was estimated by mass balance of $\mathrm{CaO}$. It is acknowledged that the accuracy of the EPMA results will have a significant effect on the accuracy and thus value of the resulting mass balances. At the same time, the results obtained (Table 4) are reasonably self consistent. They indicate that loss of fluoride from the fluorspar flux with consequent increase in slag $\mathrm{CaO}$ content has actually decreased the lime dissolution. With both the ilmenite and nepheline syenite fluxes, there has been an increase in dissolution of $\mathrm{CaO}$ with time and flux addition. This is in accord with the data in the literature where addition of ilmenite and nepheline syenite has reduced the viscosity of slag with comparable effects with $\mathrm{CaF}_{2} \cdot{ }^{10-13,16,17)}$

With the addition of the fluorspar, ilmenite and nepheline syenite fluxes to the slag, no $\mathrm{Ca}_{2} \mathrm{SiO}_{4}$ layer was observed in the experiments, and $\mathrm{CaO}$ content of slag increased more rapidly with time (Table 4). Consequently, it would appear that flux addition might either prevent the formation of $\mathrm{Ca}_{2} \mathrm{SiO}_{4}$ layer or if a $\mathrm{Ca}_{2} \mathrm{SiO}_{4}$ layer is formed, dissolve the layer with the net effect of an increased lime dissolution rate.

Quaternary $\mathrm{CaO}-\mathrm{SiO}_{2}-\mathrm{Al}_{2} \mathrm{O}_{3}-\left(\mathrm{FeO}_{x}, \mathrm{TiO}_{2}, \mathrm{Na}_{2} \mathrm{O}\right)$ phase diagrams constructed using FactSage, ${ }^{20)}$ show that addition of nepheline syenite and ilmenite does not prevent formation of di-calcium silicate at $1600^{\circ} \mathrm{C}$. However, it is known, ${ }^{21)}$ that addition of $\mathrm{FeO}_{x}, \mathrm{TiO}_{2}, \mathrm{Na}_{2} \mathrm{O}$ and $\mathrm{K}_{2} \mathrm{O}$ decreases the viscosity of the slag. Decrease in the slag viscosity with addition of nepheline syenite and ilmenite accelerated the dissolution of $\mathrm{Ca}_{2} \mathrm{SiO}_{4}$ into the molten slag.

\section{Conclusions}

The dissolution of dense lime in molten $\mathrm{CaO}-\mathrm{SiO}_{2}-$ $\mathrm{Al}_{2} \mathrm{O}_{3}$ slags was studied at temperatures of $1500^{\circ} \mathrm{C}$ and $1600^{\circ} \mathrm{C}$ by reaction of slags with a lime crucible. The effects of different fluxing agents and time of reaction were investigated. Ilmenite was the most effective flux and nepheline syenite was comparable to fluorspar, increasing the lime dissolution. When slag was reacted in the lime crucible at $1500^{\circ} \mathrm{C}$, a di-calcium silicate layer was formed between the slag and $\mathrm{CaO}$ crucible, however at $1600^{\circ} \mathrm{C}$ no dicalcium silicate layer was evident. The formation of $\mathrm{Ca}_{2} \mathrm{SiO}_{4}$ layer was experimentally verified at $1600^{\circ} \mathrm{C}$ by reaction of lime and slag in a thin platinum capsule. No $\mathrm{Ca}_{2} \mathrm{SiO}_{4}$ layer was observed in experiments with flux addition; it was either not formed or dissolved in the slag. This is a major factor in explaining the increased rate of lime dissolution in the slag.

\section{Acknowledgement}

The project is financially supported by Australian Research Council, The University of New South Wales, CSIRO Minerals and Abel Metal Services Pty. Ltd. The authors greatly appreciate the scientific expertise and laboratory facilities at CSIRO Minerlas. The authors also acknowledge the assistance in EPMA analysis by Mr. Barry Searle at The University of New South Wales and Mr. Roger Curtin at The University of Melbourne for SEM analysis.

\section{REFERENCES}

1) Y. Satyoko and W. E. Lee: Bri. Ceram. Trans., 98 (1999), 261.

2) M. Umakoshi, K. Mori and Y. Kawai: Trans. Iron Steel Inst. Jpn., 24 (1984), 532.

3) P. Williams, M. Sunderland and G. Briggs: Ironmaking Steelmaking, 9 (1982), 150.

4) J. W. Evans and C. A. Natalie: Proc. of Int. Iron and Steel Cong., 3rd, American Society for Metals, Chicago, (1979), 365.

5) C. A. Natalie: $\mathrm{PhD}$ dissertation, University of California Berkeley, 
ISIJ International, Vol. 47 (2007), No. 1

(1978).

6) M. Matsushima, S. Yadoomaru, K. Mori and Y. Kawai: Trans. Iron Steel Inst. Jpn., 17 (1977), 442.

7) F. Noguchi, Y. Ueda and T. Yanagase: Proc. World Min. Met. Technol., Vol. 2, American Institute of Mining, Metallurgical and Petroleum Engineers, New York, (1976), 685.

8) H. Kimura, T. Yanagase, F. Noguchi and Y. Ueda: J. Jpn. Inst. Met., 38 (1974), 226.

9) W. J. Schlitt and G. W. Healy: Am. Ceram. Soc. Bull., 50 (1971), 954.

10) W. F. Caley and J. B. MacDonald: Ironmaking Steelmaking, 28 (2001), 96.

11) J. R. MacLean, P. W. Kingston, J. B. MacDonald and W. F. Caley: Ironmaking Steelmaking, 24 (1997), 406.

12) T. S. Tribe, P. W. Kingston and W. F. Caley: Can. Metall. Q., 36 (1997), 95.

13) T. S. Tribe, P. W. Kingston, J. B. MacDonald and W. F. Caley: Ironmaking Steelmaking, 21 (1994), 145.
14) P. W. Kingston and W. F. Caley: Miner. Eng., 2 (1989), 207.

15) R. H. Nafziger and G. W. Elger: New Steelmaking Technology From the Bureau of Mines, Chicago, Illinois, USA, (1988), 23-7.

16) B. N. Singh, Y. F. Ravat, A. Chatterjee and P. K. Chakravarty: Ironmaking Steelmaking, 4 (1977), 170

17) D. Poggi and H. Y. Lee: Can. Metall. Q., 13 (1974), 529.

18) K. Shimizu, T. Suzuki, I. Jimbo and A. W. Cramb: Seventy Ninth Conf. of the Steelmaking Division of the Iron and Steel Society, Iron and Steel Society/AIME, Pittsburgh, (1996), 727.

19) MATLAB, The Math Works, Inc, USA, (2000).

20) C. W. Bale, P. Chartrand, S. A. Degterov, G. Eriksson, K. Hack, R. Ben Mahfoud, J. Melancon, A. D. Pelton and S. Petersen: FactSage, École Polytechnique CRCT, Canada and GTT-Technologies GmbH, Germany, (2003).

21) V. D. Eisenhuttenleute: Slag Atlas, 2nd ed, Verlag Stahleisen GmbH, Düsseldorf, (1995), 21. 